\title{
Parent's Attitude Towards Importance of Education of The Children
}

\author{
Roofen julious, Reg \# PBSN02163007 \\ Lahore School of Nursing \\ The University of Lahore \\ Lahore, Pakistan \\ Muhammad Afzal, associate professor \\ Lahore School of Nursing \\ The University of Lahore \\ Lahore, Pakistan \\ Muhammad Hussain, Assistant Professor \\ Lahore School of Nursing \\ The University of Lahore \\ Lahore, Pakistan \\ Prof. Dr. Syed Amir Gilani \\ Lahore School of Nursing \\ The University of Lahore \\ Lahore, Pakistan
}

\begin{abstract}
ABSTRECT
Introduction: Although parent's attitude regarding the importance of children education is very important and plays a vital role. If the parent's attitude is positive then they send and facilitate their children for education.

Methods: This quantitative descriptive cross-sectional study. The 22 items questionnaire was used and distributed to 153 rural community participants of Hussein Abad, Lahore, Pakistan to assess the attitude of parent's towards importance of education.

Results: Over results of the study revealed that parent's attitude was positive regarding children education. The 02 tables have been used to show results. It is divided into 2 section $1^{\text {st }}$ section shows demographic variable which involve gender, age, education, number of school going children, and house type. $2^{\text {nd }}$ section shows the likert scale which contains 22 items questionnaire. The results of the study and discussion show that rural community has positive attitude regarding children education.
\end{abstract}

Conclusions: The majority of parents were in favor for the education of their children. The government should put strict laws and open school in rural community.

Keywords- Attitude, community, education, participants

DOI: $10.7176 / \mathrm{JHMN} / 67-13$

Publication date:October $31^{\text {st }} 2019$

\section{INTRODUCTION}

Human nature is very complex and multidimensional in nature. Attitude is general element of human's nature. During one's life, every one of us develops many kinds of attitude. Attitude is a positive or negative feeling that an individual holds about the object, person or ideas. In simple words, an attitude is available that may be directly observed and can be inferred from one's own behavior through his verbal and non-verbal responses (Dhiman, 2015).

The family makes the cultural and social unification of their children instead of school. Turnbull presented 4 parental role in his study in which includes parents as teacher, decision maker and parents as advocator for their children. The attitude of parents is so important; it is necessary for children at school work and as well as at home and especially for those children who disable to perform daily life activity (Samal, 2012).

The study conducted to assess the parent's attitude towards education and how can education help their children to take ahead in their life. In this study the thoughts of parents also assess regarding the education of children and also schooling is an essential part of life. Parents attitude about education help to children to get promotin and gain progress in their life. To assess the response of parents who bleive in the rural community regarding education is 
an barrier to increase income in future. The parents thinking about the better education will help their children to get a good job and provide opportunities to earn according to their needs (Samal, 2012).

To check the response of parents regarding learning programme in the school such as workshop, discussion or extracurricular activities help the children to learn more as the comparison of practical skill in real life and their suggestion about things which are learned by thestudent in the school are relevant to real life or not. The thinking of parents about thefuture life of the children and role of education in the light of challenges and opportunities which are facing by children in actual life.In this study, we also measure the attitude mean behavior of parents toward the time which is child spend in the school for gaining knowledge is important or not which could have otherwise been spent in earning or job (Samal, 2012).

When parents are unsuccessful to be engage in children education according requirement, its considers parents ignorance according to law. According to Kafas, parental carelessness is failure to maintain children basic physical and psychological needs. The result of the parental ignorance is impairment in mental development. Kafas also comments that if the parents are fail to fulfill the need, such as provision of food, accommodation, clothes, security, and medical treatment then the parents are show carelessness and negligence from his or her responsibility.(Edward Nyongesa Oundo, 2014).

In this study the role of parents according to their socio-economic condition and involvement in education of their children and as well as their approaches regarding learning were discussed and also assess. Parental favorable attitude towards the education of their children is beneficial to regulate the attendance in school. The result of positive attitude of parents about education is positive engagement of parents with children regarding education and its motivate the students for future study. The strategies which were plan by Board of Govemors (B.O.G), parent's teachers association (P.T.A) and the meeting were fail to increase academic performance. Parents were unworried on regarding education of their children and unsatisfactory efforts have been showed by school administration to change parent's negative attitude. Anyhow the attitude of parents could be accountable for the good or poor education outcomes of students. (District Education Office, 2011).

RESEARCH QUESTION 1 - What is the attitude of parents towards importance of education of children in rural community Lahore?

AIMS OF THE STUDY

The basic aim of the study to assess and examine the parental attitude regarding the importance of children education.

SIGNIFICANCE OF THE STUDY

This study could help to enhance knowledge and make skillful in research for students and as well as beneficial for the community that they acknowledge about the basic and sensitive issue and also got awareness as being the part of this study. The findings of study could help the stakeholder of Husain Abad to arrange seminar and workshops in their community to increase the interest of parents regarding children education. The government may take help via reading this research and its result and may be make appropriate strategies to take literacy rate up. More ever, this study gives recommendation which can be helpful for the policy makers while making improvements in the education system in rural community.

\section{LITERATURE REVIEW}

The important research studies conducted regarding the attitude of parents towards the children education has been discussed as under;

TNS Social research conducted in 2003-2004 and it identify that the parent's attitude towards children education is very positive. The most of respondent of this research were agreed as $97 \%$ that a good education is helpful for his or her child to get ahead in life. On the other hand 93\% parents shows their thought in the favor of the education is an essential for their children for better future. Meanwhile $90 \%$ parents were agreed that their children adopt essential life skill at school and educational setup. The $76 \%$ respondents show that the schooling is good for their children. The majority $86 \%$ parents were agreed that their children will get good job opportunities if they become educated. Only $22 \%$ parents shows unfavorable attitude regarding education (TNS Social research (September 2003-June 2004)

More ever just 7\% respondents agreed that the schooling effects on children home life. Only $18 \%$ respondents thought that most of thing a child learn in the school are not relevant to actual life. Only $14 \%$ parents were thoughts it is reasonable that if their children do not agree to study now, they can study when they were old. Their education was based on to recognize and whether there were any dissimilarity in attitude of parents. This research has not recognized any dissimilarity in the attitude of parents in the overall population. TNS Social research (September 2003-June 2004).

The qualified parents had more positive attitude towards higher education than less educated (Shah, Sharma et al. 1991). The Michigan Department of education in 2002 identify that while there was parental involvement in 
children education, such as support the learning via activities, reading at home, the children will great academic achievement, higher attendance in school and higher self-esteem.

The parental attitude regarding school and education of children and socio-economic situation of the parents had a positive relation. At home an unfavorable relation with the academic development of students in rural and urban areas.

Blanka \& Nada 2007 identify in his research that the parents enhancement regarding education is the result of the effect of cultural and academic profile of the family and active attitude of the parents regarding education. Radu in 2011 identify that Parents with high school level of qualification will become parents' representatives rather than parents with a university.

The sex differences were also identifying to be non-significance. A research conducted by Bala in $2013, \mathrm{He}$ identify that the parents related to the age group of 20 to 30 were found to have a unfavourable attitude in context to the parents belong to the age group 21 to 30 and 41 to 50 regarding school and children education. Oostdam \& Hooge discus in 2013 in their study, that the involvement in educational activities with children at home (homework, reading, modeling), parents communicate their expectation for progress.

Parents' engagement has become a big qualification problem since 1980's. The school going children spent nearly $70 \%$ of their time in school, parent's engagement become very essential for improvement in children (Cotton \& Wikelund, 2001).

Number of researcher has been stated that the activities stated above were contributed towards student's development. Many researches have been stated that the parents are engaged in their children learning process in all kinds of children and age group of children. The parent's positive involvements in early childhood education a healthy condition and an effective resource of children development (Stagelin, 2003).

\section{CONCEPTUAL FRAMEWORK}

Attitude and Behavior.

An attitude is "a relatively enduring organization of beliefs, feelings, and behavioral tendencies towards socially significant objects, groups, events or symbols" (Hogg \& Vaughan 2005, p. 150). Affective component: this involves a person's feelings/emotions about the attitude object. For example: "Parents know that the education is necessary for their children". Behavioral component: the way the attitude we have influenced how we act or behave. For example: "parents show interest and positive behavior and send their children to school". Cognitive component involves a person's belief/knowledge about an attitude object. For example: "Parents believe that qualification will help their children to get achievement in future". The model mention bellow called ABC model of attitude. This shown in a study by LaPiere (1934).

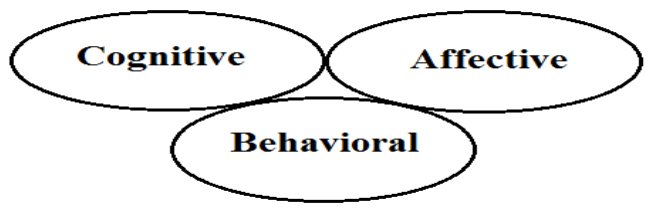

All these three components are affecting the parental attitude towards their children education and schooling. If these three components are positive than parents then individual feeling, action, and belief should be positive. On the other hand, if these three components are negative then individual feeling, action, and belief should be negative. The theory guide with its three component and gives prediction about parents attitude either it is negative or positive.

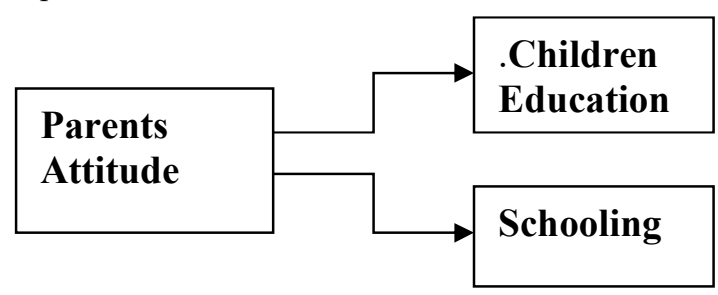

\section{METHODS}

\section{SETTING}

Data was collected from married male and female having school going children living in a Husain Abad a rural area of Lahore. RESEARCH DESIGN 
A quantitative cross-sectional descriptive study conducted at Husain Abad a Rural Area of Lahore. POPULATION

The study population is Husain Abad community and target population is married couples. SAMPLING

Data was collected using convenient sampling technique. RESEARCH INSTRUMENT

A questionnaire was designed for this study to gather data to answer the research questions. DATA GATHERING PROCEDURE

The 23 questionnaire were used to gather data from a married couple of age group is 18 to 50 years. The parents will require to their responses agree or disagree thoughts with every questionnaire about education of children in a four-point Likert type scale, where denotes 4 option from strongly agree to strongly disagree. The questionnaire adopted from the article "parents attitude towards schooling and education of the children" (Samal, May 2012). Urdu questionnaire will be used, data will be collected via door to door visiting.

ANALYZE DATA

The study will analyze the data of parents which have 2 or more than 2 school going children by SPSS. Statistical analysis of the study will be descriptive. The study sample will be characterized by using a measure of central tendency (mean, median, and mode). The descriptive data will be about demographic data which include age, gender, education independent variable will be attitude and dependent variables will education..

Informed about the goal of the research, and what will happen with the information shared. This information will provide in writing and verbally. After being adequately informed and upon agreeing to participate, the participants will request to give their consent in writing. All participants who took part in the research study will inform about the publication of the results. This aspect will also in

STUDY TIMELINE

The Study duration was 4 months from September 2017 to December 2017. ETHICAL CONSIDERATION

It will be must ensure that all the participants are adequately and fully clude in the inform consent letter IBR, community stakeholder and from the participants.

\section{RESULTS}

PROFILE OF THE RESPONDENTS

The study population is Husain Abad community and target population is married couples. 153 participants were response against questionnaire in which includes 81 male and 72 female.

Data collected from the rural residents of the Husain Abad community, Lahore to determine the attitude of parent towards importance of children education, and they show $100 \%$ response to the current study. The data analysis consists of two parts. Demographic is the first part of data analysis which gives details about demographic variables. Second part is descriptive analysis which provides us recurrence and rate of respondent regarding 22 item of questionnaire.

$\underline{\text { Section } 1}$

Table 1 Demographic data analysis

\begin{tabular}{|c|c|c|c|c|}
\hline S.N & Demographic & Group & Frequency & Percent \\
\hline 1 & Gender & Male & 81 & $52.9 \%$ \\
\hline \multirow{5}{*}{$\underline{2}$} & \multirow{5}{*}{ Age } & Female & 72 & $47.1 \%$ \\
\hline & & Total & 153 & $100 \%$ \\
\hline & & $18-25$ year & 33 & $21.6 \%$ \\
\hline & & 26-33 year & 56 & $36.6 \%$ \\
\hline & & $34-41$ year & 42 & $27.5 \%$ \\
\hline \multirow{5}{*}{$\underline{3}$} & \multirow{5}{*}{ Education } & $42-50$ year & 22 & $14.4 \%$ \\
\hline & & Total & 153 & $100 \%$ \\
\hline & & Primary & 69 & $45.1 \%$ \\
\hline & & Secondary & 20 & $13.1 \%$ \\
\hline & & Secondary lower & 19 & $12.4 \%$ \\
\hline
\end{tabular}




\begin{tabular}{|c|c|c|c|c|}
\hline & & $\begin{array}{l}\text { No formal } \\
\text { qualification }\end{array}$ & 45 & $29.4 \%$ \\
\hline \multirow{3}{*}{$\underline{4}$} & \multirow{3}{*}{$\begin{array}{l}\text { Number of } \\
\text { school going } \\
\text { children? }\end{array}$} & Total & 153 & $100 \%$ \\
\hline & & $1-2$ & 71 & $46.4 \%$ \\
\hline & & $3-4$ & 65 & $42.5 \%$ \\
\hline \multirow{5}{*}{$\underline{5}$} & \multirow{5}{*}{$\begin{array}{l}\text { Is the home } \\
\text { you live in? }\end{array}$} & $5-6$ & 17 & $11.1 \%$ \\
\hline & & Total & 153 & $100 \%$ \\
\hline & & Owned & 75 & $49 \%$ \\
\hline & & Rented & 78 & $51 \%$ \\
\hline & & Total & 15 & $100 \%$ \\
\hline
\end{tabular}

Above table depicts that participants of the study were $n=153$, male 81 and female were 72 .

18-25 year old participants were responded as 21.6\%, 26-33 year old participants were responded as 36.6\%, 3441 year old participants responded as $26.8 \%$ and $42-50$ year old participants responded as $14 \%$. The statistical report shows in table 1 that the participants between the ages of 26-33 year old percentage is high between selected age group and 42-50 year old is low.

Mostly participants' education was (45\%) Primary, (13.1\%) secondary, (12.4\%) secondary lower, and (29.4\%) not qualified. Forth demographic variable is number of school going children. The $46.4 \%$ participants have $1-2$ School going children, $42.5 \%$ have 3-4 School going children and 11.1\% have 5-6 School going children. Fifth demographic variable is the home where participant live is owned or ranted. The $49 \%$ participants have their own residency but the $51 \%$ live as rented.

Demographic data involve gender, age, qualification, number of school going children and home type is further individually described as bellow.

Section 2

Attitude of parent towards importance of children education.

In reaction of (1-22) items questionnaire which were used to determine the attitude of participants towards the importance of children education majority of the respondent's express positive attitude by circle their response in the favor of children education. Majority of them shows positive attitude but, little percentage of participants show negative attitude. Complete details presents in above table.

Each question is further individually described as bellow. It indicate the number of participants were response as agree to disagree. Descriptive analysis independent variable attitude of parents towards importance of depended variable children education.

The results of first question which was "A good education help my child to get ahead in life?" The parents responded so positively and 120 (76.4\%) participants response as strongly agree. 20 (12.7\%) Participant response as agree and $13(8.3 \%)$ response as disagree.

The results of second question which was, Education is not an indispensable part of life?" 94(59.9\%) participant responses as disagree. 55 (35\%) Participants respond as agree and $4(2.5 \%)$ response as strongly disagree. The result

Shows that majority of participant were disagree and only 4 participants were strongly agree.

The response of participants against the question 3 was very positive and favors the importance of children education. $66=42.0 \%$ parents were agreed and $54=34.4 \%$ were strongly agree that the qualification will help their children for his all over progress in life. Although the $19.7 \%$ were disagree and only 2 parents were strongly disagree.

In the reaction of question number 04 most of the participants were disagree or strongly disagree and little amount of parents were agree. Above table shows that $79=50.3 \%$ parents were disagree, $33.1 \%$ parents were disagree and $19=12.1 \%$ were agree only 3 participants were strongly agree.

The fifth question was "better educational qualification will help in getting better jobs?" Once again parents showed positive attitude. Majority of participants responded in the favor of children education. Statistical analysis shows that $64=40.8 \%$ and $63=40.1 \%$ participants were agreed and strongly agree. $23=14.6 \%$ participants were disagreeing and only 3 were strongly disagreeing. 
Table 2 Questions analysis

1. Strongly agree 2 . Agree 3 Dis-agree 4 . Strongly agree.

\begin{tabular}{|c|c|c|c|c|c|}
\hline $\mathrm{SN}$ & Question & 1 & 2 & 3 & 4 \\
\hline$\underline{1}$ & $\begin{array}{l}\text { A good education will help my } \\
\text { child to get ahead in life. }\end{array}$ & $\begin{array}{c}120 \\
78.4 \%\end{array}$ & $\begin{array}{l}20 \\
13 . \\
1 \%\end{array}$ & $\begin{array}{c}13 \\
8.5 \\
\%\end{array}$ & 00 \\
\hline$\underline{2}$ & $\begin{array}{l}\text { Education/schooling is not an } \\
\text { indispensable part of life. }\end{array}$ & $\begin{array}{c}4 \\
2.6 \%\end{array}$ & $\begin{array}{l}55 \\
35 \\
\%\end{array}$ & $\begin{array}{l}94 \\
61 \\
4 \%\end{array}$ & 00 \\
\hline$\underline{3}$ & $\begin{array}{l}\text { Education will help my child for } \\
\text { his all-round development. }\end{array}$ & $\begin{array}{c}54 \\
35.3 \%\end{array}$ & $\begin{array}{l}66 \\
43 . \\
1 \%\end{array}$ & $\begin{array}{l}31 \\
19 . \\
7 \%\end{array}$ & $\begin{array}{c}2 \\
1.3 \\
\%\end{array}$ \\
\hline$\underline{4}$ & $\begin{array}{l}\text { Education is an obstacle in the path } \\
\text { of income in near future. }\end{array}$ & $32 \%$ & $\begin{array}{l}19 \\
12 . \\
4 \%\end{array}$ & $\begin{array}{l}79 \\
51 \\
6 \%\end{array}$ & $\begin{array}{l}52 \\
34 \\
\%\end{array}$ \\
\hline$\underline{5}$ & $\begin{array}{l}\text { Better educational qualification } \\
\text { will help in getting better jobs. }\end{array}$ & $\begin{array}{c}63 \\
41.2 \%\end{array}$ & $\begin{array}{l}64 \\
41 . \\
8 \%\end{array}$ & $\begin{array}{l}23 \\
15 \\
\%\end{array}$ & $\begin{array}{c}3 \\
2 \%\end{array}$ \\
\hline$\underline{6}$ & $\begin{array}{l}\text { It does not matter whether a child } \\
\text { starts going to school early or late } \\
\text { in life. }\end{array}$ & $\begin{array}{l}2 \\
1.3 \%\end{array}$ & $\begin{array}{l}20 \\
13 . \\
1 \%\end{array}$ & $\begin{array}{l}98 \\
64 . \\
1 \%\end{array}$ & $\begin{array}{l}33 \\
21 \\
6 \%\end{array}$ \\
\hline$\underline{7}$ & $\begin{array}{l}\text { My child learns important life skills } \\
\text { at school. }\end{array}$ & $\begin{array}{c}64 \\
41.8 \%\end{array}$ & $\begin{array}{l}81 \\
52 . \\
9 \%\end{array}$ & $\begin{array}{c}7 \\
4.6 \\
\%\end{array}$ & $\begin{array}{c}1 \\
0.7 \\
\%\end{array}$ \\
\hline$\underline{8}$ & $\begin{array}{l}\text { Parents should encourage their } \\
\text { children to study well. }\end{array}$ & $\begin{array}{c}49 \\
32 \%\end{array}$ & $\begin{array}{l}91 \\
59 . \\
5 \%\end{array}$ & $\begin{array}{c}13 \\
8.5 \\
\%\end{array}$ & 00 \\
\hline$\underline{9}$ & $\begin{array}{l}\text { Whatever is taught in school can } \\
\text { easily be carried out at home. }\end{array}$ & 00 & $\begin{array}{l}28 \\
18 . \\
3 \%\end{array}$ & $\begin{array}{l}101 \\
66 \\
\%\end{array}$ & $\begin{array}{l}24 \\
15 \\
\%\end{array}$ \\
\hline$\underline{10}$ & $\begin{array}{l}\text { I am interested to send my child to } \\
\text { school every day and discourage } \\
\text { absence even for a day. }\end{array}$ & $\begin{array}{c}60 \\
39.2 \%\end{array}$ & $\begin{array}{l}74 \\
48 . \\
4 \%\end{array}$ & $\begin{array}{l}19 \\
12 . \\
4 \%\end{array}$ & 00 \\
\hline$\underline{11}$ & $\begin{array}{l}\text { Learning programmes in school } \\
\text { will not teach my child the practical } \\
\text { skills to solve real life problems. }\end{array}$ & $\begin{array}{c}2 \\
.3 \%\end{array}$ & $\begin{array}{l}65 \\
42 . \\
5 \%\end{array}$ & $\begin{array}{l}78 \\
51 \\
\%\end{array}$ & $\begin{array}{c}8 \\
5.2 \\
\%\end{array}$ \\
\hline$\underline{12}$ & $\begin{array}{l}\text { Education will help my child for } \\
\text { future opportunities and challenges } \\
\text { in life. }\end{array}$ & $\begin{array}{c}38 \\
24.8 \%\end{array}$ & $\begin{array}{l}83 \\
54 . \\
2 \%\end{array}$ & $\begin{array}{l}32 \\
20 . \\
9 \%\end{array}$ & 00 \\
\hline$\underline{13}$ & $\begin{array}{l}\text { Most of the things my child learns } \\
\text { at school are not relevant to real } \\
\text { life. }\end{array}$ & $\begin{array}{c}1 \\
0.7 \%\end{array}$ & $\begin{array}{l}37 \\
24 . \\
2 \%\end{array}$ & $\begin{array}{l}99 \\
64 . \\
7 \%\end{array}$ & $\begin{array}{l}16 \\
10 . \\
5 \%\end{array}$ \\
\hline 14 & $\begin{array}{l}\text { It gives me satisfaction that my } \\
\text { child is able to avail the benefit of } \\
\text { schooling. }\end{array}$ & $\begin{array}{c}53 \\
34.6 \%\end{array}$ & $\begin{array}{l}87 \\
56 . \\
9 \%\end{array}$ & $\begin{array}{l}13 \\
8.5 \\
\%\end{array}$ & 00 \\
\hline$\underline{15}$ & $\begin{array}{l}\text { Schooling takes away valuable time } \\
\text { from my child's life which could } \\
\text { have otherwise been spent in } \\
\text { earning/jobs. }\end{array}$ & 00 & $\begin{array}{l}54 \\
35 . \\
3 \%\end{array}$ & $\begin{array}{l}88 \\
57 \\
5 \%\end{array}$ & $\begin{array}{l}11 \\
7.2 \\
\%\end{array}$ \\
\hline$\underline{16}$ & $\begin{array}{l}\text { My child likes to attend his school } \\
\text { regularly. }\end{array}$ & $\begin{array}{c}15 \\
9.9 \%\end{array}$ & $\begin{array}{l}62 \\
40 . \\
8 \%\end{array}$ & $\begin{array}{l}65 \\
42 . \\
8 \%\end{array}$ & $\begin{array}{c}10 \\
6.6 \\
\%\end{array}$ \\
\hline$\underline{17}$ & $\begin{array}{l}\text { It is very rarely that I talk to my } \\
\text { child about his problems at school } \\
\text { or studies. }\end{array}$ & $\begin{array}{c}4 \\
2.6 \%\end{array}$ & $\begin{array}{l}34 \\
22 . \\
4 \%\end{array}$ & $\begin{array}{l}96 \\
63 \\
2 \%\end{array}$ & $\begin{array}{l}18 \\
11 . \\
5 \%\end{array}$ \\
\hline$\underline{18}$ & $\begin{array}{l}\text { 1It is very rare that I detain my } \\
\text { child from school for any } \\
\text { household work or problem. }\end{array}$ & $\begin{array}{c}28 \\
18.3 \%\end{array}$ & $\begin{array}{l}87 \\
56 . \\
9 \%\end{array}$ & $\begin{array}{l}37 \\
24 . \\
2 \%\end{array}$ & $\begin{array}{l}1 \\
0.7 \\
\%\end{array}$ \\
\hline$\underline{19}$ & $\begin{array}{l}\text { I will not face any real problem in } \\
\text { future if I did not send my child to } \\
\text { school. }\end{array}$ & $\begin{array}{c}3 \\
2 \%\end{array}$ & $\begin{array}{l}94 \\
61 . \\
4 \%\end{array}$ & $\begin{array}{l}48 \\
31 \\
4 \%\end{array}$ & $\begin{array}{c}8 \\
5.2 \\
\%\end{array}$ \\
\hline$\underline{20}$ & $\begin{array}{l}\text { How my child performs in class is } \\
\text { important to me. }\end{array}$ & $\begin{array}{c}31 \\
20.3 \%\end{array}$ & $\begin{array}{l}106 \\
69 . \\
3 \%\end{array}$ & $\begin{array}{l}16 \\
10 \\
5 \%\end{array}$ & 00 \\
\hline$\underline{21}$ & $\begin{array}{l}\text { When my child grows up to be an } \\
\text { adult, it hardly matters if he } \\
\text { attended school or not. }\end{array}$ & 00 & $\begin{array}{l}16 \\
10 \% \\
5 \%\end{array}$ & $\begin{array}{l}120 \\
76 \\
4 \%\end{array}$ & $\begin{array}{l}17 \\
10 . \\
8 \%\end{array}$ \\
\hline$\underline{22}$ & $\begin{array}{l}\text { Schooling makes my child lazy and } \\
\text { unresponsive to family problems. }\end{array}$ & 00 & $\begin{array}{c}8 \\
5.2 \\
\%\end{array}$ & $\begin{array}{l}115 \\
75 \\
2 \%\end{array}$ & $\begin{array}{l}30 \\
19 . \\
6 \%\end{array}$ \\
\hline
\end{tabular}


The selected population was respond against the question 6 as $98=62.4 \%$ participant were disagree and $33=21.0$ were strongly disagree with to join school early or late in life. $20=12.7 \%$ and $2=2.3 \%$ were disagreeing and strongly disagree from the total sample size.

Above table shows that the $81=51.6 \%$ and $64=40.8 \%$ participants were agreed or strongly agreed with the child learn more important skill at school. On the other hand some participants were not agreed with the question 7 . Only the $7=4.5 \%$ participants were disagreed.

In the response of question 8 participants show positive behavior. 91 (58.0\%) participants were agree, 49 (31.2\%) were strongly disagree and only $13(8.3 \%)$ were disagree.

$101(63.3 \%)$ participants were disagree, $24(17.8 \%)$ were strongly agree and only $20(15.3 \%)$ were agree with whatever taught in school can easily carried out at home.

$60(38.2 \%)$ participants were strongly agree, 74 (48.4\%) were agree and only $19(12.4 \%)$ were disagree with question "I am happy to send my children to school regularly and discourage absentism".

$78(51.0 \%)$ participant were disagree, $65(42.5 \%)$ were agree, $8(5.2 \%)$ were strongly disagree and only $2(1.3 \%)$ were strongly agree with that "learning programme in schooling will not teach my children the skill to solve real issues".

In reaction of question number 12 which is "qualification will help my children for future planning and challenges in life" 83 (52.9\%) participants were agree, 38 (24.2\%) were strongly agree and 32 (52.9\%) participants were disagree.

$99(63.1 \%)$ participants were disagree, $16(10.2 \%)$ were strongly disagree, $37(23.6 \%)$ were agree and only 1 $(0.6 \%)$ was strongly agree with the many things that my children learn via education are not related to actual life. $87(55.4 \%)$ participants were agree, $53(33.8 \%)$ were strongly disagree and on $13(8.3 \%)$ were disagree with bellow mentioned statement. "it satisfy e that my children avail the benefits of school independently. In the reaction of question number 15 which was "schooling takes away valuable time from my Childs life which could have otherwise been spent in earning/jobs" 88 (56.1\%) participants were disagree, $11(7.0 \%)$ strongly disagree and 54 $(38.4 \%)$ were agree and no anyone strongly agree.

$65(41.4 \%)$ participants were disagree, $62(39.5 \%)$ were agree, $15(9.6 \%)$ strongly agree, and only $10(6.4 \%)$ were strongly disagree.

In the reaction of question \# 17 which was "it is very rarely that I talk to my child about his problems at school and studies" 96 (61.1\%) participants were disagree, $18(11.45 \%)$ strongly disagree, $34(21.7 \%)$ agree and only 4 $(2.5 \%)$ were strongly agree.

$87(55.4 \%)$ participants were agree, $37(21.7 \%)$ disagree, $28(17.8 \%)$ were strongly agree and only $1(0.6 \%)$ strongly disagree that I will detained my child for any house hold activity or problem..

$94(59.9 \%)$ participants were agree, $3(1.9 \%)$ strongly agree, $48(30.6 \%)$ were disagree and $8(5.2 \%)$ were strongly disagree with the following statement "I will not face real problem in future if I did not sent my child to school". $106(67.55 \%)$ participants were agree, $31(19.7 \%)$ were strongly agree and $16(10.2 \%)$ were disagree about how their children perform in class is important for them.

The participants respond against the question number 21 that was "when my child grows up to be an adult, it hardly matters if he/she attended school or not?" 120 (75.4\%) participants were disagree, $17(10.8 \%)$ were strongly disagree and only $16(10.2 \%)$ were agree.

The response of participant against question 22 which was Schooling makes my child lazy and unresponsive to family problems? The participant $115(73.2 \%)$ responses as disagree and $30(19.1 \%)$ responded as strongly disagree only $8(5.1 \%)$ go with agree. It means the majority parents gave their opinion in the favor of children education and show positive attitude.

Descriptive analysis of attitude towards importance of children education

The outcomes exhibit $110(71.00 \%)$ respondents indicate favorable attitude towards children education responses against 22 items questionnaires. 43(29\%) responded shows (disagree and strongly disagree) unfavorable attitude.

\section{DISCUSSION}

Overall, the parental attitude to be found favorable regarding the importance children education. The study focus on the reality that grow awareness towards literacy and qualification. The value regarding to school and qualification of children has been improved compared to back when the literacy rate is low and unfavorable attitude towards the education of children is a big barrier for sending children to school.

The more parental' attitude towards schooling of the children was improved. The many of parents were responses positively. But the some parents were responded as negative. Now days the importance of education is highly appreciated by population through accountable efforts and give awareness via technology.

\section{LIMITATIONS}

There are many limitation found for this study;

$>$ The duration for this study was too short. 
$>$ This study only was focus on rural community.

$>$ Likert scale questionnaire has been used in this study.

$>$ Data collection faced lot of issues.

$>$ The participants of the study were careless and non-cooperative regarding to fill the questionnaire.

Participants of the study have not an idea about the significance of the filling questionnaire.

\section{CONCLUSION}

The current study investigates the attitude of parents of rural community towards importance of children education in Lahore. The 2 have been used to show results. The results of the study and discussion show that rural community has positive attitude, the results shows that majority of parents were in favor for the education of their children. The government should put strict laws and open school in rural community.

\section{ACKNOWLEDGEMENT}

This research was biggest step for me and that was not possible without the guidance and enlightenment blessed by God. So I thank to God for the blessings.

I would like to thank my research supervisor Mr. Muhammad Hussain for his support and guidance throughout the course of this research study and for providing an excellent role model for a novice researcher.

I would like to thanks Ms. Chanda Jabeen, being a lecturer she teach the basics of research by her excellent teaching strategies.

I would like to thanks authorities of university who gave me permission to collect data from the community. I am also thankful to the participants who actively participated, and gave me their precious time and information in this research.

I would also thanks to my mother, wife, sisters and my cute son Jason who stood by me and bear my not attending to them in busy days of my research study.

Last but not least, I am very thankful to Mr. Muhammad Sabir who being teacher of English subject supports me and correction without any benefit.

\section{REFERENCES}

Samal, R. (2012). Parents' attitude towards schooling and education of children.

Ben-Yehuda, S., et al. (2010). "Teacher educational beliefs and sociometric status of special educationalneeds (SEN) students in inclusive classrooms." International Journal of InclusiveEducation14(1): 17-34.

Brouwers, A. and W. Tomic (2000). "A longitudinal study of teacher burnout and perceived self-efficacyin classroom management." Teaching and Teacher education16(2): 239-253.

Crozier, G. and J. Davies (2007). "Hard to reach parents or hard to reach schools? A discussion of homeschool relations, with particular reference to Bangladeshi and Pakistani parents. "British Educational Research Journal33(3): 295-313.

Dauber, S. L. and J. L. Epstein (1993). "Parents' attitudes and practices of involvement in inner-city elementary and middle schools. "Families and schools in a pluralistic society: 53-71.

Gillespie, E. B., and A. P. Turnbull (1983). "It's My IEP! O Involving Students in the Planning Process." Teaching Exceptional Children16(1): 26-29.

McLoyd, V. C. (1989). "Socialization and development in a changing economy: The effects of paternal job and income loss on children." American Psychologist44(2): 293.

Moses, D. and P. Croll (1987). "Parents as partners or problems?" Disability, Handicap \&Society2(1): 75-84.

Owlia, M. S. (1996). "Quality in thehigher education-a survey. "Total Quality Management 7(2): 161-172.

Shader, M. (2001). Risk factors for delinquency: An overview, US Department of Justice, Office of Justice Programs, Office of Juvenile Justice and Delinquency Prevention.

Shah, B., et al. (1991). "Knowledge, attitude and practice of immunization in an urban educated population." Indian journal of pediatrics58(5): 691-695.

Yarnold, P. R., et al. (1998). "Predicting patient satisfaction: a study of two emergency departments." Journal of Behavioral Medicine21(6): 545-563. 